\title{
Morphological Characterization and Relationship between Morphometric Parameters and Standard Length Barbus altianalis (Boulenger, 1904) Populations in Lake Victoria Drainage Basin, Kenya
}

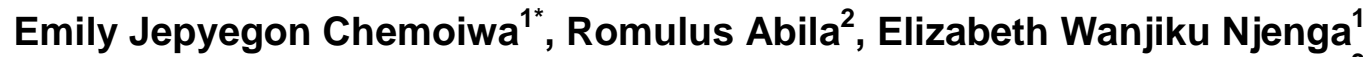 \\ and James Barasa ${ }^{3}$ \\ ${ }^{1}$ Department of Biological Sciences, University of Eldoret, P.O.Box 1125-30100, Eldoret, Kenya. \\ ${ }^{2}$ Department of Environmental Studies, Forestry and Agriculture, Maasai Mara University, \\ P.O.Box 861-20500, Narok, Kenya. \\ ${ }^{3}$ Department of Fisheries and Aquaculture, University of Eldoret, P.O.Box 1125-30100, Eldoret, \\ Kenya.
}

Authors' contributions

This work was carried out in collaboration between all authors. Author EJC designed the study, collected data and performed the statistical analysis, wrote the protocol and the first draft of the manuscript. Author RA collected data and wrote the protocol. Authors EWN and JB managed the analyses of the study. All authors managed the literature searches. All authors read and approved the final manuscript.

Article Information

DOI: $10.9734 / A R R B / 2017 / 31984$ Editor(s):

(1) Tony Gutierrez, School of Life Sciences, Heriot-Watt University, UK.

(2) George Perry, University of Texas at San Antonio, USA.

Reviewers:

(1) Claudine Tekounegning Tiogué, The University of Dschang, Cameroon. (2) U. D. Enyid, University of Agriculture, Nigeria. Complete Peer review History: http://www.sciencedomain.org/review-history/20075

Original Research Article

Received $1^{\text {st }}$ February 2017 Accepted $15^{\text {th }}$ June 2017 Published $17^{\text {th }}$ July 2017

\begin{abstract}
Aim: To provide data on external morphology of Barbus altianalis from four major rivers in Lake Victoria watershed, determine whether there are significant morphometric differences between subpopulations from the rivers of the catchment area examined and to determine relationship between morphometric parameters and standard length (SL).

Methods and Results: Morphometric analysis was carried out in the study. Based on 21
\end{abstract}


morphometric characters, Barbus altianalis populations from four Lake Victoria catchment rivers Nzoia, Yala, Nyando and Sondu-Miriu were morphologically characterised based on 21 morphometric parameters. Principal Component Analysis (PCA) showed separation of Rivers Yala from Nzoia, Nyando, and Sondu-Miriu populations. Factor loadings established that 11 characters were morphologically informative. PCA1 accounted for $43.25 \%$ of the variation while PCA2 accounted for $19.44 \%$ of the variation. Mann-Whitney $U$ Test $(\alpha=0.05)$ indicated lack of significanct difference in morphological characteristics between Sondu-Miriu and Nyando, but significant intraspecific morphological difference between all the other pairs of rivers. All external parameters except 4 showed positive relationship with standard length (SL). Our results suggests presence of intra-specific morphometric variation between the four populations and corroborate findings based on mitochondrial DNA analysis.

Conclusion: Morphological characterization reveal intra specific variation in Barbus altianalis in the Lake Victoria catchment and suggests the existence of river specific morphs, a possible adaptation to changes in the catchment. This could also provide evidence of long term existence of migratory as well as riverine sedentary populations of the species within Lake Victoria basin (LVB).

Keywords: Barbus altianalis; lake victoria; principal component analysis; intra-specific variation; morphometrics.

\section{INTRODUCTION}

Lake Victoria is found in East Africa is the world's largest freshwater lake by surface area. The lake is a source of livelihood to millions of riparian communities is currently at the verge of extinction as result of over exploitation of its fisheries resources, invasive species, pollution as well as well as unsustainable land use practices in its watershed and changing climatic conditions. Securing the long term ecological integrity of the lake ecosystem and its biota is major global conservation and sustainable development concern. Besides its previously diverse cichlid ichthyofauna, the cyprinidae is another taxa that have undergone severe species decline in the last four decades in the Lake Victoria Basin (LVB).

Species belonging to the cyprinid genus Barbus (Cuvier and Cloqueet 1816) constitute a very diverse group. They are considered polyphyletic with about 1146 species [1] and occupy a wide range of different habitats [2,3]. Many African species assigned to the genus Barbus belong to two distinct groups - "small" and "large" barbels differing especially in adult size and type of scale striation [4-7]. Small barbs' are diploid $(2 n=50)$ characterised by an adult size of $<10 \mathrm{~cm}$ standard length, and by diverging striae on the exposed part of their scales. This is in contrast to the 'large barbs', subgenus Labeobarbus (Ruppell, 1836), which are hexaploid $(2 n=150)$, have parallel striae and a larger dorsal spine [8]. $2 n$ states that appear to be multiples of an ancestral 2N state of 50 observed in Barbus may present evidence of past whole-genome duplication (WGD) in this group [9] It is generally acknowledged that this cyprinid taxon requires a complete taxonomic reorganization of its status [10] and morphological characters have been used to address this problem in various studies [3,11,12].

Fish diversity in natural lakes is higher due to more stable environmental conditions under which fish evolve. In contrast, riverine species have to live under harsher and more variable environmental conditions [13] and these could influence morphological plasticity of riverine fish species [14]. Morphological changes can be a result of adaptation to abiotic and biotic factors [15] There have been relationships between environmental and morphological characteristics among taxa of Barbus [16]. However, these relationships have been affected when a given morphological structure used for more than one function is subject to multiple selection or when adjacent structure perform different functions so that one structure influences a second character [16]. Such functional morphological versatility have been widely investigated among the cichlids [17] where they have been used to show that the differences between the populations is probably a phenotypic response to differing abiotic factors such as river size, flow velocity and food availability. Whether such mechanisms also influence Barbus populations have not been investigated.

Due to their migratory nature, Barbus are particularly prone to the effects of environmental perturbation. The possibility of two populations of many riverine species in River Sondu-Miriu has been reported [18]. Studies on trophic ecology [19] and current molecular studies [20] suggest 
the existence of non-migratory Barbus altianalis populations within the Lake Victoria catchment. It is not clear whether such changes from potamodromous to stationary behavior has been accompanied by morphological changes among populations of the species. Morphological characters are important in fish species identification [21], while growth is important in the evolutionary persistence of a fish species in the habitat, their assessment are important in assessing evolutionary changes in a population. The morphological changes that may have accompanied adaptations to a sedentary mode of life in the Lake Victoria basis have not been assessed in this fish community.

The purpose of this study was therefore to use morphometric analysis of characters to distinguish and describe the populations of Barbus altianalis from the four rivers in Lake Victoria watershed. The objective of the current study was to provide data on external morphology of Barbus altianalis from four major rivers in Lake Victoria watershed, determine whether there are significant morphometric differences between sub-populations from the rivers of the catchment area examined and to determine the relationship between morphometric parameters and the standard length (SL).
It has been hypothesized that there could have been 2 populations of Barbus altianalis within the Lake Victoria Basin (LVB): The now 'extinct' migratory Lake Victoria population and a river restricted non-migratory population. Long term existence of sedentary populations should be manifested through significant differences in morphology between the four populations.

\section{MATERIALS AND METHODS}

\subsection{Study Area}

A few Sampling sites identified by Ojwang in his study on two riverine species [19] and adopted by the study by Chemoiwa [20] were used in this study (Fig 1). The selected sites were georeferenced using Geographical Positioning System (GPS) to ensure accurate sampling was carried throughout the study period. Specimens sampled in [20] study were used in morphometric analysis. Samples were collected from the following stations, Nzoia-Ugunja Bridge and Nzoia-Webuye before discharge on Nzoia River; Yala water works and Yala Kakamega Bridge on Yala River; Nyando-Ahero and Nyando-Koru on Nyando River and Sondu-Nyakwere and Sondu Bridge on Sondu-Miriu River.

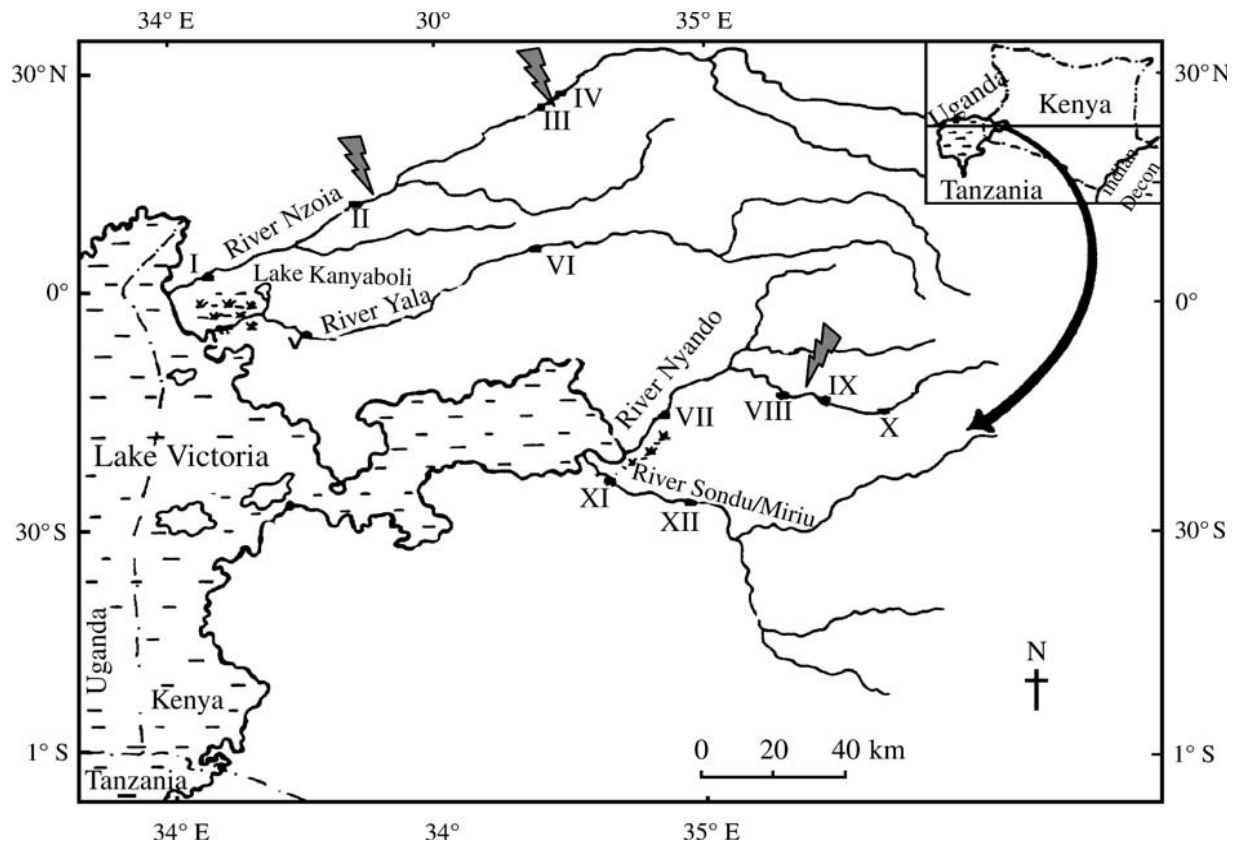

Fig. 1. Main rivers draining the Kenyan side of Lake Victoria and stations sampled (I, NzoiaUgunja Bridge; IV, Nzoia-Webuye before discharge; V, Yala water works; VI, Yala Kakamega Bridge; VII, Nyando-Ahero; X, Nyando-Koru; XI, Sondu-Nyakwere; XII, Sondu-Sondu Bridge). Map modified from [17] 


\subsection{Sample Collection and Treatment}

At each sampling site, samples were collected through electrofishing. Fishes were identified to species level using identification keys and photographs in [1]. All other species were released back to the river except Barbus altianalis. 196 individuals were collected from the four rivers at approximately equal male: Females ratios. Total length ( $T L ; \mathrm{cm})$, standard length $(\mathrm{SL}$; $\mathrm{cm}$ ) and total weight (TW; g) were determined on site. Data on sex and stage of gonadal maturity in all the individuals was also obtained following sexing schemes in [22]. Specimens were preserved in $4 \%$ buffered formalin, packed in plastic containers and transported to the laboratory and finally preserved in $70 \%$ ethanol. The following morphometric data were taken from the left side of the fish body: Standard length (SL), Body depth (BD), Head length (HL), Snout length (SnL), Eye diameter (ED), Interorbital width (IOW), Dorsal fin base length (DFB), Anal fin base length (AFB), Predorsal length (PDL), Preanal length (PAL), Prepectoral length ( $P P L)$, Preventral length ( $P V L)$, Caudal peduncle length (CPL), Caudal peduncle depth (CPD), Pelvic fin base length (PvFB), Pectoral fin base length (PFB), Length of the anterior barbell (LAB), Length of the posterior barbel (LPB), Occipital length $(\mathrm{OcL})$, Total length (TL) and Total weight (TW).

\subsection{Statistical Analysis}

External morphometric characters data obtained from this study were entered in MS Excel spreadsheets for storage while analysis was done using PAST [23] and MINITAB version 14. Mean values for each morphometric character measured from the Barbus altianalis collected from each of the four sites in Lake Victoria catchment, Kenya were computed and summarized in a table as mean \pm SEM. One-way Analysis of Variance (ANOVA) was performed to test for significance in the variations in each morphometric character between the rivers.

Morphometric data were log-transformed and subjected to a Principal Component Analysis (PCA) specially designed to remove size effects, i.e. the 'sheared' PCA [23]. This was done to remove size related effects on shape among groups of individuals of non-overlapping sizeclasses. In this analysis, PCA was carried out using the covariance matrix to obtain eigenvalues and loading [24]. PCA was used to find hypothetical variables (components) that account for as much of the variance in a multidimensional morphometric dataset as possible $[25,26]$. In this analysis the first principal component (PC-I) integrates size-related variation, whereas the PC-II is theoretically sizefree. The non parametric Mann-Whitney $U$ test was performed on the components identified from PCA loadings for univariate comparisons to evaluate differences between groups on characters contributing most to variation.

To determine the relationship between the external morphometric characters studied with respect to standard length, linear regression analysis was carried out and the strength of the relationship determined using the $R^{2}$ value while $\mathrm{p}$-value was used to determine the significance of the relationship. Analysis of Covariance (ANCOVA) for the four populations was done to test for equality of slopes in the relationships and hence show morphometric differences among the populations.

\section{RESULTS}

\subsection{Morphometric Characteristics}

Table 1 shows the mean values for the morphometric characteristics determined during the study. The values of all external morphometric parameters were highest in the River Nzoia population followed by Sondu-Miriu and Nyando while River Yala population had the lowest morphometric measurements. The total length and total weight for example of Barbus altianalis from River Nzoia were the largest of all the four populations $(20.44 \pm 0.78 \mathrm{~cm}$, and $108.12 \pm 10.46 \mathrm{~g}$ respectively) while that of river Yala were the smallest $(13.38 \pm 0.65 \mathrm{~cm}$ and $34.53 \pm 8.94$ respectively). The Length of anterior barbell $(F=1.174, p=0.320)$ and the length of the posterior barbel $(F=0.165, p=0.920)$ did not vary significantly between the populations at $\alpha=0.05$. All the other morphometric characteristics measured varied significantly among the four populations.

\subsection{Principal Component Analysis (PCA)}

The PCA on the morphometric data showed limited separation of the polygons of the four popalations (Fig 2, Table 2). There was slight separation on the first component with most of fish from river Yala being on the negative part of the first principal component, whereas those from river Nzoia were on the positive part. Populations of rivers Sondu-Miriu and Nyando did not show 
any clear separation in both the first and second components. PCA 1 accounted for $43.25 \%$ of the

differences while PCA2 accounted for $19.44 \%$ of the difference.

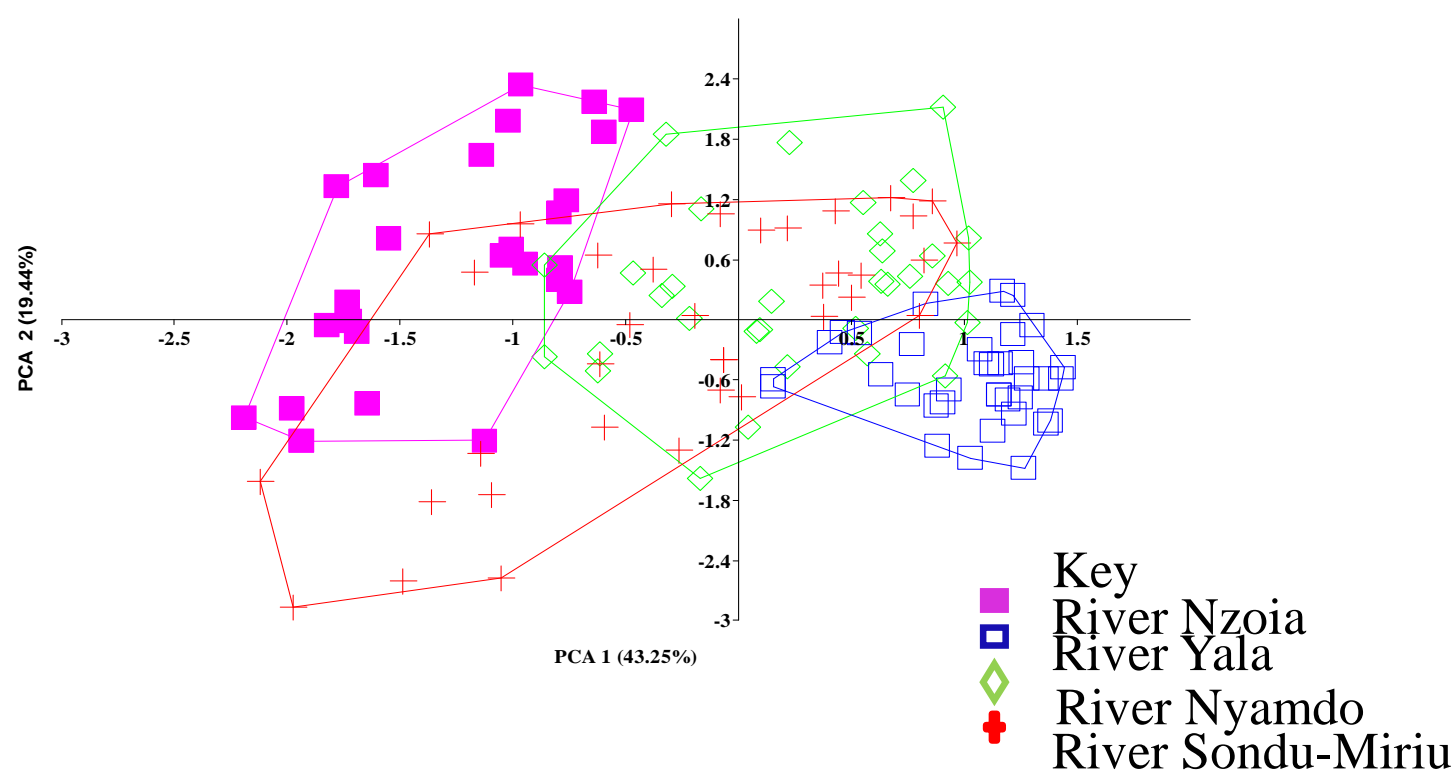

Fig. 2. Plot of individual scores on the first and second components on metrics aspercent of standard length of Barbus altianalis specimens from the rivers draining to Lake Victoria Kenyan basin

Table 1. Mean \pm SEM of the external morphometric characteristics from the Barbus altianalis collected from four sites in Lake Victoria, Kenya. (Values in parenthesis are the minimum and maximum values measured for each of the morphometric parameter, significant variation tested at $\alpha=0.05), P<0.0005$

\begin{tabular}{lllllll}
\hline Traits & \multicolumn{3}{c}{ Sites } & \multicolumn{2}{c}{ ANOVA } \\
\cline { 2 - 7 } & Sondu-Miriu & Yala & Nzoia & Nyando & F & P-value \\
\hline TL & $17.21 \pm 0.70$ & $13.38 \pm 0.65$ & $20.44 \pm 0.78$ & $16.67 \pm 0.60$ & 17.781 & $\mathrm{P}<0.0005$ \\
TW & $61.45 \pm 7.25$ & $34.53 \pm 8.94$ & $108.12 \pm 10.46$ & $58.55 \pm 7.16$ & 12.972 & $\mathrm{P}<0.0005$ \\
SL & $12.91 \pm 0.57$ & $9.90 \pm 0.46$ & $15.72 \pm 0.61$ & $12.63 \pm 0.49$ & 19.684 & $\mathrm{P}<0.0005$ \\
BD & $3.12 \pm 0.15$ & $2.40 \pm 0.14$ & $4.12 \pm 0.19$ & $3.10 \pm 0.12$ & 22.491 & $\mathrm{P}<0.0005$ \\
HL & $3.46 \pm 0.15$ & $2.81 \pm 0.11$ & $3.91 \pm 0.15$ & $3.42 \pm 0.14$ & 10.805 & $\mathrm{P}<0.0005$ \\
ED & $0.86 \pm 0.03$ & $0.76 \pm 0.02$ & $0.91 \pm 0.03$ & $0.76 \pm 0.02$ & 10.956 & $\mathrm{P}<0.0005$ \\
SnL & $0.59 \pm 0.03$ & $0.46 \pm 0.03$ & $0.69 \pm 0.03$ & $0.59 \pm 0.03$ & 9.540 & $\mathrm{P}<0.0005$ \\
DFB & $1.79 \pm 0.09$ & $1.55 \pm 0.09$ & $2.28 \pm 0.09$ & $1.85 \pm 0.07$ & 13.372 & $\mathrm{P}<0.0005$ \\
AFB & $0.94 \pm 0.05$ & $0.77 \pm 0.04$ & $1.14 \pm 0.06$ & $0.94 \pm 0.04$ & 9.635 & $\mathrm{P}<0.0005$ \\
PDL & $7.19 \pm 0.30$ & $5.83 \pm 0.28$ & $8.48 \pm 0.32$ & $7.23 \pm 0.29$ & 13.100 & $\mathrm{P}<0.0005$ \\
PAL & $9.79 \pm 0.44$ & $7.53 \pm 0.37$ & $11.69 \pm 0.48$ & $9.43 \pm 0.35$ & 17.115 & $\mathrm{P}<0.0005$ \\
PPL & $3.66 \pm 0.14$ & $3.04 \pm 0.12$ & $4.29 \pm 0.17$ & $3.52 \pm 0.12$ & 13.816 & $\mathrm{P}<0.0005$ \\
PVL & $6.78 \pm 0.29$ & $5.25 \pm 0.26$ & $7.91 \pm 0.29$ & $6.56 \pm 0.24$ & 16.385 & $\mathrm{P}<0.0005$ \\
CPL & $2.19 \pm 0.11$ & $1.73 \pm 0.09$ & $2.65 \pm 0.11$ & $2.11 \pm 0.08$ & 15.140 & $\mathrm{P}<0.0005$ \\
CPD & $1.45 \pm 0.07$ & $1.05 \pm 0.07$ & $1.98 \pm 0.09$ & $1.47 \pm 0.06$ & 27.580 & $\mathrm{P}<0.0005$ \\
LAB & $0.53 \pm 0.03$ & $0.57 \pm 0.04$ & $0.63 \pm 0.03$ & $0.61 \pm 0.05$ & 1.174 & 0.320 \\
LPB & $0.71 \pm 0.05$ & $0.69 \pm 0.04$ & $0.69 \pm 0.03$ & $0.72 \pm 0.04$ & 0.165 & 0.920 \\
PvFB & $0.59 \pm 0.04$ & $0.41 \pm 0.03$ & $0.71 \pm 0.04$ & $0.62 \pm 0.06$ & 8.431 & $\mathrm{P}<0.0005$ \\
PFB & $0.49 \pm 0.03$ & $0.39 \pm 0.02$ & $0.64 \pm 0.04$ & $0.48 \pm 0.03$ & 12.125 & $\mathrm{P}<0.0005$ \\
OcL & $2.76 \pm 0.13$ & $2.41 \pm 0.09$ & $3.21 \pm 0.11$ & $2.77 \pm 0.10$ & 8.889 & $\mathrm{P}<0.0005$ \\
IOW & $1.05 \pm 0.06$ & $0.82 \pm 0.05$ & $1.30 \pm 0.06$ & $1.12 \pm 0.08$ & 9.917 & $\mathrm{P}<0.0005$ \\
\hline
\end{tabular}


The factor loadings established that a total of 11 variables were responsible for the morphological differences of Barbus altianalis. The first principal component was defined mostly by prepectoral length, caudal peduncle depth, and lengths of anterior and posterior barbels, whereas the second component was defined mostly by Snout length, eye diameter, body depth, preanal length, pelvic fin base length, occipital length and interorbital width (Table 2).

Mann-Whitney $U$ test (Table 3 ) for variation between pairs of rivers studied showed that all the morphometric traits of Barbus altianalis from river Sondu-Miriu except eye diameter did not vary significantly from those of river Nyando. While comparisons between rivers Sondu-Miriu and Yala differed significantly except for the length of anterior barbel. All the traits tested showed significant variations between river Yala and river Nzoia populations. The length of posterior barbel did not vary significantly between rivers Sondu-Miriu and Nzoia, SonduMiriu and Nyando, and Yala and Nzoia.

\subsection{Relationship between Morphometric Traits and Standard Length}

The growth variability of the morphometric characters was also done. In the analysis of external morphometric characteristics' growth variability of the characters studied with respect to SL (Table 4), several correlations were observed. Based on the beta (b) value all were significant $(b<0.3)$. Regression results showed that all external parameters except $\mathrm{LAB}\left(\mathrm{R}^{2}=\right.$ 47.7), CPL $\left(R^{2}=32.8\right)$, LPB $\left(R^{2}=49.3\right)$ and ED $\left(R^{2}=26.1\right)$ showed strong positive relationships with the $S L\left(R^{2}>0.5 ; p<0.001\right)$.

\subsection{Analysis of Covariance ANCOVA}

Analysis of Covariance in regression for the four populations shows morphometric differences among the populations. All the morphometric variables showed significant variation $(p<0.05)$ between the populations (Table 5) except in Anal Fin Base, Predorsal Length, Preanal Length, Prepectoral Length, Preventral Length, Caudal peduncle length, Pelvic fin base length, Pectoral fin base length and Interorbital width were the variation was not significant ( $p>0.05)$.

\section{DISCUSSION}

\subsection{Morphometric Characteristics}

Our data strongly suggest the existence of intraspecific morphometric variation of Barbus altianalis populations in the Lake Victoria catchment. Studies have shown that morphometric characters are more suitable in describing intra-specific variation since they are often influenced by several factors such as the genotypic composition, water quality, feeding habits, feed types, organism interrelationship (predation), weather conditions, and habitat type [27-29]. Any significant differences in the above factors consequently lead to variation in fish morphology. Morphometric characters in Barbus have been shown to exhibit plasticity [30,21], and this could be related to changes in fish species' habitat throughout its life [31,32].

\section{Table 2. Loadings of the per cent standard metrics on first and second principal components of Nzoia population $(n=46)$, Nyando population $(n=54)$ Sondu-Miriu population $(n=48)$ and Yala population $(n=$ 48). Most significant are in bold}

\begin{tabular}{lll}
\hline & PC1 & PC2 \\
\hline Head length \% SL & -0.1185 & 0.1066 \\
Eye diameter \%SL & -0.1826 & 0.3570 \\
Snout length \%SL & -0.1279 & -0.3008 \\
Dorsal fin base length & 0.0118 & 0.0331 \\
\%SL & & \\
Body depth \%SL & 0.0047 & -0.3348 \\
Anal fin base \% SL & -0.1605 & -0.1940 \\
Predorsal length \%SL & 0.0046 & 0.0852 \\
Preanal length \%SL & -0.0624 & -0.2331 \\
Prepectoral length \%SL & -0.2865 & 0.3110 \\
Preventral length \%SL & -0.0760 & 0.1049 \\
Caudal peduncle length \% & 0.0728 & -0.0291 \\
SL & & \\
Caudal peduncle depth \% & 0.2638 & -0.3740 \\
SL & & \\
Length of anterior barbell & -0.9607 & -0.1137 \\
\%SL & & \\
Length of the posterior & $-\mathbf{0 . 8 4 2 6}$ & 0.1087 \\
barbel \%SL & & \\
Pelvic fin base length \%SL & 0.1191 & $\mathbf{- 0 . 9 5 8 9}$ \\
Pelvic fin base \%SL & -0.1783 & $\mathbf{- 0 . 2 0 6 0}$ \\
Occipital length \%SL & -0.3156 & 0.2613 \\
Interorbital width \%SL & 0.0405 & -0.4269 \\
\hline
\end{tabular}

The lack of any variation in the morphometric characteristics of Barbus altianalis from river Sondu-Miriu and river Nyando could partly be attributed to similarity in common food types, catchment activities, weather conditions as well as geographical promixity. These populations occupy similar habitats and are generally subjected to similar environmental and selective pressures. Both rivers are located within the same catchment area with agriculture as the dominant activity [33]. Differences in length of the barbels are mostly associated with feeding and feeding habit of fish [34]. [12] found significant 
Table 3. Mann-Whitney U Test results for selected morphometric traits between the four rivers

\begin{tabular}{|c|c|c|c|c|c|c|}
\hline Variable & $\begin{array}{l}\text { Sondu Miriu } \\
\text { versus Yala }\end{array}$ & $\begin{array}{l}\text { Sondu Miriu } \\
\text { versus Nzoia }\end{array}$ & $\begin{array}{l}\text { Sondu Miriu } \\
\text { versus Nyando }\end{array}$ & $\begin{array}{l}\text { Yala } \\
\text { versus Nzoia }\end{array}$ & $\begin{array}{l}\text { Yala } \\
\text { versus Nyando }\end{array}$ & $\begin{array}{l}\text { Nzoia } \\
\text { versus Nyando }\end{array}$ \\
\hline ED & $\mathrm{P}<0.0005^{* *}(2823.5)$ & $0.0141^{*}(1824.0)$ & $0.0002^{\star *}(2612.0)$ & $\mathrm{P}<0.0005^{\star *}(1274.5)$ & $0.0783(1913.0)$ & $\mathrm{P}<0.0005^{* \star}(2838.5)$ \\
\hline SnL & $P<0.0005^{\star *}(2843.0)$ & $0.0009^{\star *}(1713.0)$ & $0.4920(2227.5)$ & $P<0.0005^{\star \star}(1169.0)$ & $P<0.0005^{\star *}(1444.5)$ & $0.0001^{\star *}(2641.5)$ \\
\hline BD & $P<0.0005^{\star *}(2882.5)$ & $P<0.0005^{\star \star}(1472.5)$ & $0.6338(2200.5)$ & $P<0.0005^{\star \star}(1103.5)$ & $P<0.0005^{\star *}(1391.0)$ & $P<0.0005^{\star \star}(2902.5)$ \\
\hline PAL & $P<0.0005^{* *}(2876.5)$ & $P<0.0005^{\star *}(1564.0)$ & $0.3427(2261.0)$ & $P<0.0005^{\star *}(1116.0)$ & $P<0.0005^{\star *}(1400.5)$ & $\mathrm{P}<0.0005^{* *}(2819.5)$ \\
\hline PPL & $\mathrm{P}<0.0005^{\star *}(2809.5)$ & $P<0.0005^{\star *}(1587.0)$ & $0.3713(2254.0)$ & $P<0.0005^{\star *}(1167.0)$ & $P<0.0005^{* *}(1522.5)$ & $\mathrm{P}<0.0005^{\star *}(2773.0)$ \\
\hline CPL & $P<0.0005^{\star *}(3182.0)$ & $P<0.0005^{\star \star}(1566.0)$ & $0.7555(2371.0)$ & $P<0.0005^{\star \star}(1199.5)$ & $P<0.0005^{\star *}(1424.5)$ & $\mathrm{P}<0.0005^{\star *}(2985.0)$ \\
\hline LAB & $0.0709(2575.0)$ & $0.0119^{*}(1947.0)$ & $0.6389(2542.5)$ & $P<0.0005^{\star \star}(1608.0)$ & $0.2475(2299.0)$ & $0.0024^{\star *}(2762.0)$ \\
\hline LPB & $0.0262^{*}(2632.0)$ & $0.2107(2114.0)$ & $0.3211(2620.5)$ & $0.0001^{* *}(1748.0)$ & $0.4328(2354.5)$ & $0.0089^{* *}(2702.0)$ \\
\hline PvFB & $P<0.0005^{\star *}(3112.5)$ & $\mathrm{P}<0.0005^{\star \star}(1804.0)$ & $0.0898(2725.5)$ & $P<0.0005^{\star \star}(1281.5)$ & $\mathrm{P}<0.0005^{\star *}(1737.0)$ & $\mathrm{P}<0.0005^{\star *}(3113.0)$ \\
\hline OcL & $P<0.0005^{\star *}(3056.5)$ & $0.0004^{\star *}(1814.5)$ & $0.1340(2696.0)$ & $P<0.0005^{\star *}(1246.5)$ & $0.0001^{* *}(1892.0)$ & $\mathrm{P}<0.0005^{\star *}(3051.0)$ \\
\hline IOW & $P<0.0005^{\star *}(3092.5)$ & $\mathrm{P}<0.0005^{\star *}(1692.5)$ & $0.3654(2607.5)$ & $P<0.0005^{\star \star}(1231.5)$ & $P<0.0005^{\star *}(1679.5)$ & $\mathrm{P}<0.0005^{\star *}(3037.0)$ \\
\hline
\end{tabular}

( $U$ values are in brackets, ${ }^{* *}$ shows significant difference at both $99 \%$ and $95 \%$ while ${ }^{*}$ shows significant difference at only $\left.95 \%\right)$

Table 4. $\mathbf{R}^{2}$ values and beta (b) values for the morphometrics measured against the standard length (bold values shows metrics that do not have strong relationships)

\begin{tabular}{|c|c|c|c|c|c|c|c|c|c|c|}
\hline \multirow[t]{2}{*}{ Dependent variable } & \multicolumn{2}{|c|}{ Sondu Miriu } & \multicolumn{2}{|c|}{ Yala } & \multicolumn{2}{|c|}{ Nzoia } & \multicolumn{2}{|c|}{ Nyando } & \multicolumn{2}{|c|}{ Overall } \\
\hline & $\mathbf{R}^{2}$ & b & $\mathbf{R}^{2}$ & b & $\mathbf{R}^{2}$ & b & $\mathbf{R}^{2}$ & b & $\mathbf{R}^{2}$ & b \\
\hline Body Depth & 91.2 & 1.018 & 86.6 & 1.256 & 91.5 & 1.144 & 86.7 & 0.900 & 93.3 & 1.102 \\
\hline Head Length & 89.6 & 0.858 & 87.0 & 0.920 & 49.7 & 0.991 & 96.1 & 0.969 & 85.2 & 0.843 \\
\hline Eye Diameter & 62.2 & 0.452 & 73.6 & 0.668 & 26.1 & 0.444 & 83.2 & 0.594 & 66.6 & 0.493 \\
\hline Snout Length & 92.1 & 1.164 & 74.7 & 1.391 & 81.7 & 1.152 & 80.4 & 1.120 & 88.4 & 1.108 \\
\hline Dorsal Fin Base & 70.3 & 0.988 & 60.3 & 1.282 & 66.4 & 0.717 & 74.9 & 0.859 & 78.4 & 0.945 \\
\hline Anal Fin Base & 88.2 & 1.161 & 72.0 & 1.277 & 57.6 & 1.091 & 81.2 & 0.985 & 83.6 & 1.024 \\
\hline Predorsal Length & 97.8 & 0.923 & 93.1 & 1.078 & 96.3 & 0.929 & 58.0 & 0.868 & 87.3 & 0.907 \\
\hline Preanal Length & 96.1 & 1.007 & 92.4 & 1.091 & 96.5 & 0.957 & 97.1 & 0.976 & 97.7 & 1.005 \\
\hline Prepectoral Length & 94.4 & 0.865 & 72.2 & 0.901 & 91.4 & 0.844 & 92.7 & 0.886 & 83.0 & 0.826 \\
\hline Preventral Length & 85.3 & 0.915 & 71.6 & 1.177 & 90.1 & 0.809 & 91.7 & 0.865 & 90.4 & 0.926 \\
\hline Caudal peduncle length & 70.3 & 0.887 & 32.8 & 1.044 & 73.4 & 0.958 & 58.1 & 0.709 & 72.0 & 0.913 \\
\hline Caudal peduncle depth & 88.8 & 1.050 & 64.3 & 1.247 & 93.9 & 1.142 & 84.6 & 0.989 & 90.3 & 1.204 \\
\hline Length of the anterior barbel & 67.9 & 1.248 & 47.7 & 1.068 & 68.8 & 1.306 & 74.2 & 1.500 & 59.2 & 0.952 \\
\hline Length of posterior barbell & 78.2 & 1.388 & 49.3 & 0.855 & 65.8 & 1.259 & 67.2 & 1.037 & 55.0 & 0.795 \\
\hline Pelvic fin base length & 79.8 & 1.149 & 64.5 & 1.790 & 89.4 & 1.098 & 77.8 & 1.033 & 83.1 & 1.215 \\
\hline Pectoral fin base length & 81.8 & 1.220 & 55.2 & 1.049 & 86.7 & 1.130 & 80.9 & 0.976 & 84.6 & 1.041 \\
\hline Occipital length & 83.8 & 0.967 & 78.3 & 0.740 & 84.9 & 0.672 & 90.8 & 0.879 & 87.3 & 0.766 \\
\hline Interorbital width & 90.9 & 1.124 & 70.4 & 1.268 & 77.0 & 1.079 & 88.4 & 1.168 & 90.6 & 1.149 \\
\hline
\end{tabular}


differences in morphometric traits between different species of Barbus in Chepkoilel reservoir in Uasin Gishu District of Rift Valley Province (Kenya) and attributed this to different feeding habits. The observed morphometric congruence between the river Nyando and river Sondu-Miriu populations observed in the current study could partly be attributed to similarities in diet and the physico-chemical parameters within the rivers.

Table $5 . R^{2}$ values and $F$ values for the morphometrics measured against the standard length. $P<0.05$ show significant variation in morphometrics between populations. (Bold values shows metrics that do not have strong relationships)

\begin{tabular}{llll}
\hline Morphometric traits & $\mathbf{F}$ & $\mathbf{P}$ & $\mathbf{R}^{2}$ \\
\hline Body Depth & 13.82 & $\mathrm{P}<0.0005$ & 94.25 \\
Head Length & 10.19 & $\mathrm{P}<0.0005$ & 91.74 \\
Eye Diameter & 8.31 & $\mathrm{P}<0.0005$ & 67.54 \\
Snout Length & 3.86 & 0.010 & 83.32 \\
Dorsal Fin Base & 2.93 & 0.035 & 83.39 \\
Anal Fin Base & 2.19 & $\mathbf{0 . 0 9 1}$ & 83.56 \\
Predorsal Length & 1.90 & $\mathbf{0 . 1 3 1}$ & 92.07 \\
Preanal Length & 1.11 & $\mathbf{0 . 3 4 7}$ & 97.59 \\
Prepectoral Length & 2.21 & $\mathbf{0 . 0 8 9}$ & 93.11 \\
Preventral Length & 1.75 & $\mathbf{0 . 1 5 9}$ & 90.36 \\
Caudal peduncle & 0.88 & $\mathbf{0 . 4 5 0}$ & 72.48 \\
length & & & \\
Caudal peduncle & 13.82 & $\mathrm{P}<0.0005$ & 93.75 \\
depth & & & \\
Length of the anterior & 16.64 & $\mathrm{P}<0.0005$ & 64.44 \\
barbel & & & \\
Length of posterior & 21.78 & $\mathrm{P}<0.0005$ & 65.12 \\
barbell & & & \\
$\begin{array}{l}\text { Pelvic fin base length } \\
\text { Pectoral fin base }\end{array}$ & 2.20 & $\mathbf{0 . 0 8 9}$ & 77.79 \\
length & 1.38 & $\mathbf{0 . 2 5 0}$ & 82.34 \\
$\begin{array}{l}\text { Occipital length } \\
\text { Interorbital width }\end{array}$ & 5.31 & 0.002 & 88.87 \\
\hline
\end{tabular}

Pairwise comparisons between rivers Yala, and Nyando, Yala and Sondu-Miriu, Yala and Nzoia, Nzoia and Nyando, Nzoia and Sondu-Miriu, based on Mann-Whitney U-Test (Table 3) indicated significant differences in morphometric traits. This could probably be due to difference in food types within the river systems. Diet has been shown to cause variation in the morphology not only in fish but also in most organisms [35, 36]. Feed types within a system determine the feeding habit of an organism. A fish may change from herbivory to carnivory especially if it is an opportunistic feeder, which will in turn alter its morphology [35], as an adaptation to enhance feeding efficiency.
The observed differences in morphometric traits may also be related to different environmental conditions such as water quality varied significantly since the rivers run through areas of relatively different altitude. Altitude greatly influences water quality parameters like temperature and turbidity, factors responsible for morphometric changes in fish. Similarly, food availability in the habitat and water depth could also be contributing to morphological changes in $B$. altianalis in the four rivers

Rivers Yala and Nzoia flow through areas of high temperatures while Nyando and Sondu-Miriu both run a catchment experiencing lower temperatures. River Sondu-Miriu has been largely viewed to have significant differences in turbidity as compared to rivers Yala and Nzoia (pers com) [37]. Variations in turbidity have been reported to influence differences in fish morphology [38-40].

All the four rivers have different water depths which could also be partly responsible for variation in morphology of $B$. altianalis. Water depth determines the size of the eye diameter of the fish. The depth further has a connection with water volume thus affecting the velocity and discharge of the river water. Fishes in high volume waters such as River Nzoia in this study are generally big as compared to those in low volume waters [27]. This is probably an adaptive mechanism of fish to aid in movement, feeding, and even defence from predation since larger water bodies have higher diversity of organisms that are interrelated. Morphometric differences among the four populations is based on Body Depth, Head Length, Eye Diameter, Snout Length, Dorsal Fin Base, Caudal peduncle depth, Length of the anterior barbell, Length of posterior barbell and Occipital length.

\section{CONCLUSION AND RECOMMENDA- TIONS}

The existence of intraspecific variation among the Lake Victoria Basin (LVB) Barbus altianalis populations, a species known to be migratory is surprising and corroborates previous findings based on stable isotope analysis of carbon sources [18] and mtDNA studies [19]. Intraspecific variation within the populations studied could suggest long term existence of previously not studied sedentary populations. We therefore hypothesize that Barbus altianalis existed in Lake Victoria Basin (LVB) as two populations: The migratory population that has 
since been decimated from the main lake and a riverine sedentary population. Alternatively, it could be argued that due to land use changes within the Lake Victoria basin catchment, the previously migratory (potamodramous) species are now restricted to specific rivers. We however discount this hypothesis since, if this were the case, we would not expect to find significant morphological variations between the populations since environmental changes in the LVB is a recent phenomenon and such populations would not have been allopatrically segregated long enough to accumulate morphological differences resulting from local adaptations.

Morphological characterization reveal intra specific variation in Barbus altianalis in the Lake Victoria catchment and suggests the existence of river specific morphs, a possible adaptation to changes in the catchment. Genetic [17] and phylogenetic studies suggest the existence of genetically differentiated populations within the catchment with river Nzoia population representing the most genetically divers and phylogenetically distinct populations and the river Nzoia population could represent a distinct sub population. The changing environmental conditions within the Lake Victoria basin could therefore be a major factor driving adaptation of this species within the Lake Victoria system. There is therefore urgent need to undertake habitat utilization studies of Barbus altianalis in the LVB since habitat utilization influences development and adaptation of various morphological features to certain environmental pressures. Management and conservation measures to and arrest anthropogenic impacts on this global biodiversity hotspot should also be given top conservation priority by riparian countries.

Future studies should employ other robust morphological analysis techniques to evaluate the variation in morphology. Such techniques provide data that can discern fine scale morphological differences between populations.

\section{COMPETING INTERESTS}

Authors have declared that no competing interests exist.

\section{REFERENCES}

1. Froese R, Pauly D. FishBase. World wide web (Pisces, Cyprinidae) from southern
Africa. Ann. Cape Prov. Electronic Publication; Mus. Nat. Hist. 2011;16:201307.

Available:http://www.fishbase.org

2. De Vos L, Seegers A, Okeyo D. The fishes of Lake Kamnarok (Kerio River drainage). (Unpublished report). National Museum of Kenya, Nairobi; 1999.

3. De Vos L, Thys e. DFE, Audenaerde VD. Petits Barbus (Pisces, Cyprinidae) du Rwanda. Reo. Hydrobiol. Trop. 1990;23(2): 141-169.

4. Banister KE. A revision of the large Barbus (Pisces, Cyprinidae) of east and central Africa. Studies on African Cyprinidae part II. . Bulletin of the british museum Natural History Zoology. 1973;26:1-148.

5. Banister KE. The Barbus perince-Barbuns eglecticus problem and a review of certain Nilotic small Barbus species (Teleostei, Cypriniformes Cyprinidae). Ibid. 1987;53: 115-138.

6. Leveque C. Biodiversity dynamics and conservation: The freshwater fishes of tropical Africa: Cambridge University Press, UK; 1997.

7. Skelton PH, Tweddle D, Jackson PBN. Cyprinids of Africa. Fish \& Fisheries Series. 1991;3:211-239.

8. Howes GJ. The phylogenetic position of the Yugoslavian cyprinid fish genus Aulopyge Heckel, 1841, with an appraisal of the genus Barbus Cuvier \& Cloqueì, 1816 and the subfamily Cyprininae. Bulletin of the British Museum of Natural History Zoology. 1987;52:165-196.

9. Stella MK, Glasauer, Stephan CF, Neuhauss. Whole genome duplication in teleot fishes and it evolutionary consequences. Molecular Genetis and Genomics. 2014;89(6):1045-1060.

10. Golubtsov AS, Krysanov EY. Karyological study of some cyprinid species from Ethiopia. The ploidy differences between large and small Barbus of Africa. Journal of Fish Biology. 1993;42:445-455.

11. Doadrio I, Carmona JA, FernandezDelgado C. Morphometric study of the Iberian Aphanius (Actinopterygii, Cyprinodontiformes), with description of a new species. Folia Zoologia. 2002;51(1): 67-79.

12. Osuka KE, Mlewa CM. Morphomeristic study of sympatric Barbus species from a man- made reservoir in upland Kenya. African Journal of Ecology. 2011; 1-7. 
13. Fernando $\mathrm{CH}$, Holcik J. Fish in reservoir. Int. Revue Ges. Hydrobiol. 1991;76:149167.

14. Gaston KA, Lauer TE. Morphometric variation in bluegill Leopomis macrochirus and green sunfish Lepomis cyanellus in lentic and lotic systems. Jnl. of Fish Biol. 2015;86:317-332.

15. Fulton CJ, Binning SA, Wainwright PC, Bellwood DR. Wave-induced abiotic stress shapes phenotypic diversity in a coral reef fish across a geographical cline. Coral Reefs. 2013;32(3):685-689.

16. Schaack S, Chapman LJ. Interdemic variation in the African cyprinid Barbus neumayeri: Correlations among hypoxia, morphology, and feeding performances. Canada Journal of Zoology. 2003;81:430440.

17. Rutaisire J, Booth AJ, Masembe C, Nyakaana S, Muwanika VB. Morphometric and genetic differentiation of two Labeo victorianus populations in L. Victoria. Journal of African Zoology. 2005;40:309317.

18. Ochumba PBO, Manyala JO. Distribution of fishes along the Sondu-Miriu River of Lake Victoria, Kenya with special reference to upstream migration, biology and yield. Aquacuiture and Fisheries Management. 1992;23:701-719.

19. Ojwang WO, Kaufman L, Soule E, Asila AA. Evidence of stenotopy and anthropogenic influence on carbon source for two major riverine fishes of the Lake Victoria watershed. Journal of Fish Biology. 2007;70:1430-1446.

20. Chemoiwa EJ, Abila R, Macdonald A, Lamb J, Njenga E, Barasa JE. Genetic diversity and population structure of the endangered ripon barbel, Barbus altianalis (Boulenger, 1900) in Lake Victoria catchment, Kenya based on mitochondrial DNA sequences. Journal of Applied Ichthyology. 2013;29(6):1225-1233.

21. Osuka KE, Mlewa CM. Morphomeristic study of sympatric Barbus species from a man-made reservoir in upland Kenya. African Journal of Ecology. 2012;50(1):5359.

22. Witte F, Van Densen WLT. The Rastrineobola fishery. Fish Stocks; 1995.

23. Hammer $\varnothing$, Harper DAT, Ryan PD. PAST Palaeontological Statistics: Paleontological statistics software package for education and data analysis. Palaeontol. Electronica. 2001;4:1-31.
24. Davis JC. Statistics and data analysis in geology. John Wiley \& Sons; 1986.

25. Harper DAT. Numerical palaeobiology. John Wiley \& Sons; 1999.

26. Costa JL, De Almeida PR, Costa MJ. A morphometric and meristic investigation of Lusitanian toadfish Halobatrachus didactylus (Bloch and Schneider, 1801): Evidence of population fragmentation on Portuguese coast. Scientia Marina. 2003;67:219-231.

27. Murta AG. Morphological variation of horse mackerel (Trachurus trachurus) in the Iberian and North African Atlantic: Implications for stock identification. Journal of Marine Science. 2000;57:1240-1248.

28. Turan C, Yalcin Ş, Turan F, Okur E, Akyurt I. Morphometric comparisons of African catfish, Clarias gariepinus, populations in Turkey. Folia Zoologia. 2005;54:165172.

29. Verep B, Turan D, KovÃ V. Preliminary results on Morphometry of Barbel (Barbus tauricus Kessler, 1877) in the Streams of Rize and Artvin (Turkey). Turkish Journal of Fisheries and Aquatic Sciences. 2006;6(1).

30. Hinder I, Jonsson B. Ecological polymorphism in Arctic Charr. Biological Journal of Linnean Society. 1993;48:63-74.

31. Peres-Neto PR, Magnan P. The influence of swimming demand on phenotypic plasticity and morphological integration: A comparison of two polymorphic Char species. Oecologica. 2004;140:36-45.

32. Mungai N, Njue AM, AH, VS. Periodic flooding and land use effects on soil properties in Lake Victoria basin. African Journal of Agricultural Research. $2011 ; 6(19): 4613-4623$.

33. Leveque C. Biodiversity dynamics and conservation: The freshwater fishes of tropical Africa: Cambridge University Press, UK; 1997.

34. Fermon Y, Cibert C. Ecomorphological individual variation in a population of Haplochromis nyererei from the Tanzanian part of Lake Victoria. Journal of Fish Biology. 1998;53:66-83.

35. Meyer A. Influence of age and size on the response to novel prey by fry of the cichlid fish Cichlasoma managuense (Pisces, Cichlidae). Ethology. 1988;78:199-208.

36. Vuai SAH, Ibembe JD, Mungai N. Spatial variation of nutrients in Sondu-Miriu and Simiyu-Duma Rivers: Implication on sources and factors influencing their 
transportation into the Lake Victoria. J Earth Sci Climate Change. 2012;3. DOI: $10.4172 / 2157-7617.1000119$

37. Cheng-Hsin L, Tsung-Yu L, Cheng-Yi H. Morphometric variation between the swordtip (Photololigo edulis) and Mitre ( $P$. chinensis) squids in the waters off Taiwan Journal of Marine Science and Technology. 2010;18:406-412.

38. Pierce GJ, Hastie LC, Guerra A, Thorpe, RS, Howard FG, Boyle PR. Morphometric variation in Loligo forbesi and Loligo vulgaris: Regional, seasonal, sex, maturity and worker differences. Fisheries Research. 1994;21:127-148.
39. Vega MA, Rocha FJ, Guerra A, Osorio C. Morphological differences between the Patagonian squid Loligo gahi populations from the Pacific and Atlantic oceans. Bulletin of Marine Science. 2002;71:903913.

40. Musa. S, Aura CM, Owiti G, Nyonje B, Orina $P$, Charo-Karisa $H$. Fish farming enterprise productivity program (FFEPP) as an impetus to Oreochromis niloticus (L.) farming in Western Kenya: Lessons to learn. African Journal of Agricultural Research. 2012;7(8):1324-1330.

DOI: 10.5897/ajar11.1606

(c) 2017 Chemoiwa et al.; This is an Open Access article distributed under the terms of the Creative Commons Attribution License (http://creativecommons.org/licenses/by/4.0), which permits unrestricted use, distribution, and reproduction in any medium, provided the original work is properly cited.

Peer-review history:

The peer review history for this paper can be accessed here: http://sciencedomain.org/review-history/20075 